\title{
Ideas of the Provincial Managers of the Ministry of National Education about Localization
}

\author{
M. Metin ARSLAN* Hasan H. ATASAYAR ${ }^{* *}$
}

\begin{abstract}
The aim of this research is to identify the points of view of the directors and inspectors of the provincial organization of the Ministry of National Education on staff, budget, site construction and restoration of building and localization in educational programs and to enlighten the studies on localization of the educational services. Our results showed that, there are meaningful differences between the opinions of the education directors and inspectors about the localization subject in terms of their titles, educational status and seniority of directorship. Education directors and inspectors mostly fall into disagreement on the subjects that education's function to ensure national unity will decrease and economic and social development will be faster with the localization.
\end{abstract}

Key Words: Education, Localization, Authority Transfer, Govermental Administrion, Local administrion

\footnotetext{
*Assist. Prof. Dr. Kırıkkale University, Faculty of Educational Sciences, mm.arslan@mynet.com

** Instructor, Kırıkkale University, Faculty of Educational Sciences, hhatasayar@mynet.com.
} 


\section{SUMMARY}

The aim of this research is to identify the points of view of the directors and inspectors of the provincial organization of the Ministry of National Education on staff, budget, site construction and restoration of building and localization in educational programs and to enlighten the studies on localization of the educational services.

The research has been developed according to the descriptive model. In order to collect data, a means of data collection which consists of 20 proposals have been applied to the sample group. The research environment is constituted by county director of national education 81 directors of county national education, 243 assistant-directors of county national education, 1709 section directors, 2676 chiefs and primary school inspector 2221 .

A total of 436 education directors and inspectors have been taken as the sample group 334 of whom are primary school inspectors, 22 assistant- directors of county national education, 24 section directors and 56 chiefs.

In the analysis of the data collected with the data collecting means Statistic Program for Social Sciences (SPSS) have been used. In the statistical analysis of the collected data unidirectional analysis-of-variant $(F)$ for unrelated groups and Scheffe test, frequency (f) percentage (\%) arithmetical average (X), standard deviation (SD) techniques have been benefited. The gained findings have been interpreted with tables and graphics.

The findings reached in the research are as the following:

The majority of the education directors and inspectors $(64 \%),(\bar{X}=2.58)$ think they cannot perform their functions effectively with the centralizing structure of the Ministry of National Education where authority to adjudicate is gathered in the upper management units.

The majority of education directors and inspectors $(70 \%),(\bar{X}=3.73)$ think that the central organization of the Ministry of National Education should transfer a part of its authorities to local organizations and that education system should be reconstructed.

Education directors and inspectors think that in case the central organization of the Ministry of National Education transfer authority to local organizations, it would be beneficial that more $(\% 74),(\bar{X}=3.82)$ ministry central organization constitute more realistic education programs using the information which comes from the local organizations and the education facilities, personnel, building and other sources which are at the local level will be used more productively.

Education directors and inspectors think that it would be disadvantageous in case central organization of the Ministry of National Education transfer authority to local organizations, because more $(\% 60),(\bar{X}=3.56)$ influential individuals among 
the people may affect education management for their own advantage, thus it would get harder to ensure equality in education and education may stray from its general goals and principles if education directors who work in local organizations take advantage of it.

The majority of education directors and inspectors $(\% 73),(\bar{X}=3.78)$ think that it would be appropriate to transfer authority to local organizations on the subjects like building schools, site, building construction, maintaining the educational facilities, maintenance and restoration and meeting the electricity, water, communication, heating expenses of the facilities.

There are meaningful differences between the opinions of the education directors and inspectors about the localization subject in terms of their titles, educational status and seniority of directorship.

Education directors and inspectors mostly fall into disagreement on the subjects that education's function to ensure national unity will decrease and economic and social development will be faster with the localization. 


\section{Milli Eğitim Bakanlığı Taşra Örgütü Yöneticilerinin Yerelleşme Konusundaki Görüşleri}

\section{Metin ARSLAN*}

\author{
Hasan H. ATASAYAR ${ }^{* *}$
}

ÖZ. Bu araştırmanın amacı; Milli Eğitim Bakanlığı taşra örgütü yöneticileri ve denetçilerinin iş gören hizmetleri, bütçe hizmetleri, genel hizmetler, eğitim programları ve öğretim ile ilgili hizmetler alanında yerelleşme konusundaki görüşlerini saptamak, eğitim hizmetlerinin yerelleştirilmesi çalışmalarına 1şık tutmaktır.

Sonuçlar eğitim yöneticilerinin ve denetçilerinin görev unvanı, eğitim durumu, yöneticilik kıdemi değişkelerine göre yerelleşme konusuna ilişkin görüşlerinde gruplar arasında anlamlı farklılıklar bulunduğunu göstermiştir. Eğitim yöneticileri ve denetçileri en fazla, eğitimin milli birliği sağlama işlevinin azalacağı ve yerelleşme ile ekonomik ve sosyal kalkınmanın daha hızlı gerçekleşeceği konularında görüş ayrılığına düşmektedirler.

Anahtar Sözcükler: Yerelleşme, Yetki Devri, Merkezden Yönetim, Yerinden Yönetim,

\section{GíRiș}

Enformasyon teknolojilerinin sağladığı imkânlarla bilişim ve iletişim alanında büyük dönüşüm ve değişimler gerçekleşmiştir. Bu gelişmeler bütün

\footnotetext{
* Yrd. Doç. Dr. Kırıkkale Üniversitesi Eğitim Fakültesi Eğitim Bilimleri Bölümü Başkanı, mm.arslan@mynet.com

** Öğr. Gör. Kırıkkale Üniversitesi Eğitim Fakültesi Eğitim Bilimleri Bölümü, hhatasayar@mynet.com.
} 
sektörleri etkilediği gibi eğitim alanında da etkili olmuştur. İçeriği giderek yaşamla daha ilişkili olmaya başlayan eğitim, bilim ve teknoloji alanındaki gelişmelere bireyin entelektüel katılımını sağlayacak araç olarak görülmektedir. İçinde bulunduğumuz çağın kendine özgü koşulları, yeni yetișen kuşakları geleceğe hazırlamada önemli rolü olan eğitim sistemimizde bazı değişimleri zorunlu kılmaktadır.

Cumhuriyetin ilanından önceki dönemde eğitim kurumları önemli devlet adamlarının çabalarıyla ve varlıklı insanlar tarafından kurulan vakıflar yoluyla desteklenmekteydi. Cumhuriyetin ilanıyla birlikte devletimiz eğitimi, nüfusun geneline yönelik "Türk Devrimi"ne dayalı "modern toplum projesini" gerçekleştirmek amacıyla yapılandırmaya çalışmıştır. Bu nedenle ilk iş olarak milli eğitim sisteminin geliştirilmesi düşünülmüştür. 3 Mart 1924 tarihinde kabul edilen Tevhid-i Tedrisat Kanunu ile Osmanlı Devleti'nden kalan geleneksel eğitim kurumlarına son verilmiştir. Ülkemizde Milli Eğitim Bakanlığının sorumluluğunda lâik eğitim sistemi kurulmuştur. Eğitim işlerinin tek elden yürütülmesi sağlanmıştır. Böylece eğitim sistemimizin merkezden yönetilmesine başlanmıştır. Merkezde güçlü bir otoritenin varlığg ve taşrada gücünü merkezi otoriteden alan valinin başında bulunduğu il sistemini meydana getiren idari örgütlenme şekli günümüzde de varlığını sürdürmektedir.

Merkezden yönetimde kanun gücü merkezde toplanır ve her iş merkezden yönetilir. Merkezi yönetim, karar alma ve bu kararları uygulama yetkisine sahiptir. Merkezden yönetimde hizmetler merkezdeki görevliler tarafindan yürütülür. Hizmetlerin yerine getirilmesi için gereken kaynaklar da merkezileşmiştir.

Merkezi yönetimin idarede birliği, hizmetlerin verimli yürütülebilmesi için uzmanlığı, hizmetlerde standardı ve hizmetlerin dengeli dağıtılmasını sağlama gibi yararlarının yanı sıra bazı sakıncaları da vardır. Merkezden yönetimde kırtasiyecilik artmakta ve yerel ihtiyaçları merkezden belirlemek zorlaşmaktadır. Bu yönetimde halkın doğrudan yönetime katılması sınırlıdır. Merkez adına görev yapan birimler, görevlerinin gereklerini yerine getirmek yerine, merkezin emirlerini uygulamayı yeğleyebilir. Çünkü yönetimin katı bir biçimde uygulanması, örgütteki bütün kararların üst düzey yöneticiler tarafından alınması ve örgütün alt birimlerinde çalışanların hemen her işi üstlerine danışarak yapmalarına neden olur (Usluel, 1995; Bucak, 2000).

Küreselleşmenin her alanda etkili olduğu günümüzde, bireyler, örğütler ve uluslar için firsatların ve risklerin arttığı bir süreç yaşanmaktadır. Devletimiz "Ekonomik ve Sosyal Gelişme Eksenleri”ne yönelik belirlenen "Yerel dinamiklere ve içsel potansiyele dayalı gelişmenin sağlanması, yerel düzey- 
de kurumsal kapasitenin artırılması, kırsal kesimde kalkınmanın sağlanması" stratejik amaçlarla yerelleşme sürecini başlatmış bulunmaktadır (DPT,2006). Bu gelişmelerle birlikte eğitim sistemimizin merkeziyetçi yapısının azaltılması, yetki ve sorumlulukların yerel örgütlere aktarılması gündeme gelmiştir.

Adem-i merkeziyet, yerinden yönetim ya da desentralizasyon gibi değişik isimlerle anılan yerelleşme; merkezde bulunan yetkilerin karar verme, planlama ve kamu hizmetlerinin yürütülmesi konularında yerel düzeydeki herhangi bir örgüte ya da kuruluşa devredilmesi anlamına gelmektedir (Usluel, 1995).

Yerelleşmede, karar verme yetkisinin, üst yönetim birimlerinden alt yönetim birimlerine devredilmesi ve yerel yönetimlere özerklik tanınması önem taşımaktadır. Ayrıca yerelleşmenin temelinde yetki ve yetki devri yer almaktadir.

Genellikle yerelleşme örgütsel ve siyasal olarak iki boyutta ele alınmaktadır. Örgütsel yerelleşme; merkezi yönetimin yetkilerinin alt birimlere hiyerarşik olarak devredilmesi demektir. Siyasal yerelleşme ise yarı bağımsız yerel denetim biçimi anlamına gelmektedir.

Yerelleşmenin biçimleri konusunda bir ayrım da yerelleşmenin dereceleri arasında yapılmaktadır. Buna göre yerelleşmenin yetki genişliği, yetki devri ve yerinden yönetim olmak üzere üç biçimi vardır.

Yetki; bir örgütün üyelerinin örgütün amaçlarını gerçekleştirmeye yönelik davranmalarını sağlayan yönetim gücüdür. Yetki genişliği, merkezi yönetimin yerel nitelikli hizmetlerinin yürütülmesi amaciyla yetkisini kendine bağlı birimlere aktarmasıdır. Yetki genişliği ilkesinde merkezi yönetimden yerel örgütlere daha çok iş akışı olmaktadır. Dolayısıyla kararlar merkezi yönetim birimlerinde alınır. Alınan kararlar ise yerel örgütler tarafından uygulanir.

Merkezi yönetim; merkezden uzaktaki örgütlere bazı işlevlerin yürütülmesine yetecek kadar yetkiyi merkez adına kullanmak üzere devredebilir. Yetki devri; örgütün amaçlarını gerçekleştirmek amacıyla yetkinin üst yöneticilerinden alt yöneticilerine aktarılmasıdır. Bir başka tanıma göre yetki devri; işlevsel veya yönetsel nitelikte anlamlı görev ve sorumlulukların astlara verilmesidir. Yetki devri karar verme sürecinde astların daha özerk olmasını sağlamaktadır (Elma, 2003:182). Yetki devri ilkesiyle yerel örgütlere daha fazla karar yetkisi tanınmıştır. Ancak, asıl yetkiler yine merkezde tutulmaktadır. Merkezi yönetim, devrettiği yetkilerini yasal bir düzenleme yapmadan bir duyuruyla geri alabilir. Yetki devredilmesiyle birlikte yetki 
devredilen kişi sorumluluk üstlenmektedir. Bununla birlikte üst yöneticinin yetki devrini gerçekleştirdiği görevlerindeki sorumluluğu devam eder.

Yerelleşmenin diğer bir biçimi de yerinden yönetimdir. Yerinden yönetim; kamu hizmetlerinin yönetim işlerinin, merkezi yönetim dışındaki örgütlere verilmesidir. Yerinden yönetim ilkesinde, merkezi yönetim ve yerel yönetimin yetkileri birbirinden ayrılmıştır. Merkezi yönetim ve yerel yönetim kendine ait yasal yetkilere ve sorumluluklara sahiptir.

Yerinden yönetimin siyasal ve idari olmak üzere iki biçimi vardır. Siyasal yerinden yönetimlere federal devletler örnek verilebilir. İdari yerinden yönetim biçiminde yerel örgütlere yalnız yürütme ile ilgili görevler verilmiştir. Yerinden yönetiminin temel özelliği, özerkliğe dayanmasıdır. Yerinden yönetim örgütlerinin kendine ait bütçeleri vardır. Yerinden yönetim, merkezi yönetimin vesayet denetimi ile kontrol edilir (Keleş, 2000: 20).

Dünyada olduğu gibi ülkemizde de toplumsal yapı ve işleyişin değişimi eğitim sisteminde yaşanan sorunların çözümünü güçleştirmiştir. Sorunların çözümünü kolaylaştıracağı ümidiyle güçlendirilmeye çalışılan bürokrasi kendisinden umulan yararı göstermek bir yana yapılan işlerin verimliliğini tartış1lır hale getirmiştir (Bozan, 2002). Ülkemizde meydana gelen teknolojik, ekonomik, politik, kültürel gelişmelere koşut olarak eğitimin her kademesinde hizmet alma talebi artmıştır. Bu talepleri karşılamak üzere kalkınma planları, hükümet programları, milli eğitim şurâlarında belirlenen politika ve ilkelere rağmen henüz istenilen sonuca ulaşılması mümkün olmamıştır. İstenilen sonuçlara ulaşılmamasının nedenlerinin başında yetkilerin merkezde, üst yönetim birimlerinde toplanması ve üst yönetimde s1k s1k değişikliğin yapılması görülmektedir. Bu durum Altıncı Beş Yıllık Kalkınma Planı'nda Türkiye'nin ekonomik ve sosyal yönden kalkınmasına engel olan faktörlerin aşırı merkeziyetçilik, yetki-sorumluluk dengesizliği, verimsizlik ve gereksiz formalite ile kırtasiyecilik olduğu şeklinde dile getirilmiştir. Ayrıca On dördüncü Milli Eğitim Şurâsı'nda enerji, para ve zaman kaybına neden olan kırtasiyeciliğin yaygın olduğu, eğitim sisteminin alt sistemleri arasında koordinasyonun zayıf olduğu, yetkilerin üst yönetimde toplandığ 1 vurgulanarak merkezi yönetimin güçlükleri belirtilmiştir (www.dpt.gov.tr.).

Kamu yönetimi sisteminin çağdaş bir yönetim anlayışına uygun bir yapıya kavuşturulması amacıyla ulusal öncelikler ile yerel farkl11ıklar uzlaştırılarak kamu hizmetlerinin yerinden karşılanmasının temel ilke olması, merkezî yönetim tarafından yürütülmesi zorunlu olmayan hizmetlerin, kaynaklaryyla birlikte yerel yönetimlere devredilmesi hedeflenmiştir. Yerel Yönetim reformu çerçevesinde, merkezî idare ile yerel idareler arasında görev, yetki ve kaynak paylaşımının, üniter devlet anlayışına dayalı olarak, etkinlik, ve- 
rimlilik ve çağdaş yönetim ilkelerine uygun olarak yeniden belirlenmesi hedeflenmiştir.

İl idareleri yeniden yapılandırılarak; Bakanlıkların taşradaki görev ve yetkilerinin, valiliklere ve il özel idarelerine devredilmesi ve yerel tercihler dikkate alınarak, eğitim hizmetlerinin il düzeyinde karşılanmasına yönelik çabalar sürmektedir.

Eğitim alanında yaşanan güçlüklerin çözüme kavuşturulması amacıyla merkezi yönetimden yerinden yönetime geçiş için model arayışları sürdürülmekte ve bu konuda çalışmalar yapılmaktadır. Ancak yerinden yönetimin; bürokratik gecikmelerin azaltılması, merkezin yükünün hafifletilmesi, yöre halkının ihtiyaç duyduğu eğitim hizmetlerinin daha hızlı ve ekonomik bir şekilde karşılanması gibi yararlarının yanı sıra eğitim standartlarının yöreden yöreye farkl1l1k göstermesi, yerel örgütlerde koordinasyon zorluğunun ortaya çıkması, yöre halkından ileri gelenlerin yerel örgütler üzerinde söz sahibi olması, seçimle gelen yöneticilerin halk tarafindan daha çok ilgi gören hizmetlere öncelik verip diğer hizmetleri savsaklaması gibi sakıncalar bulunmaktadır (Usluel, 1995). Bu sakıncalar nedeniyle Milli Eğitim Bakanlığında yerelleşme konusu uzun süre gündemde kalacak ve tartış1lacak bir konu olmaya devam edecektir.

\section{Araştırmanın Amacı}

Araştırma, Milli Eğitim Bakanlığı taşra örgütünde görev yapan eğitim yöneticileri ve denetçilerinin Milli Eğitim Bakanlığg merkez örgütünün elinde bulunan bir kısım yetkilerin yerel örgütlere devredilmesi durumunda ortaya çıkacak yarar ve sakıncalar ile yerel örgütlere devredilmesi öngörülen eğitim hizmetleri konularına ilişkin görüşlerini değerlendirmeyi amaçlamıştır. Bu amaç çerçevesinde, Milli Eğitim Bakanlığı taşra örgütü yöneticileri ve denetçilerinin iş gören, genel bütçe, eğitim programları ve öğretim hizmetleri alanlarında yerelleşme konusundaki görüşlerine başvurularak şu sorulara cevap aranmıştır:

(1)Milli Eğitim Bakanlığı taşra örgütünde görev yapan eğitim yöneticileri ve denetçilerinin Milli Eğitim Bakanlığının merkeziyetçi yapısı ve merkez örgütünün taşra örgütlerine yetki devretmesi konusundaki görüşleri nedir? (2)Milli Eğitim Bakanlığı taşra örgütü yöneticileri ve denetçilerinin taşra örgütlerine yetki devredilmesinin yararları ve sakıncaları konusundaki görüşleri nedir?(3)Milli Eğitim Bakanlığı taşra örgütü yöneticileri ve denetçilerinin; iş gören, eğitim programları ve öğretim, bütçe, genel hizmetler konularında yerel örgütlerin yetkili olması konusundaki görüşleri nedir? (4)Milli Eğitim Bakanlığı taşra örgütü yöneticileri ve denetçilerinin görüşleri arasında;görev unvanlarına, eğitim durumlarına, yöneticilik kıdemlerine göre anlamlı farklılık var midır? 


\section{YÖNTEM}

$\mathrm{Bu}$ araştırmada, betimsel tarama modeli kullanılmıştır. Araştırmanın evrenini 2004-2005 öğretim yılında Milli Eğitim Bakanlığ il milli eğitim müdürlüklerinde görev yapan yöneticiler (81 il milli eğitim müdürü, 243 il milli eğitim müdür yardımcısı, 1709 şube müdürü, 2676 şef) ile 2221 ilköğretim müfettişi oluşturmaktadır. Evreni oluşturan eğitim yöneticileri ve denetçilerinin tamamına ulaşmak güç olduğundan örnekleme yoluna gidilmiştir. Milli Eğitim Bakanlığ 1 taşra örgütünde görevli 400 ilköğretim müfettişi ile il milli eğitim müdür yardımcısı, şube müdürü, şef unvanlarına sahip toplam 111 eğitim yöneticisi örneklem grubunu oluşturmuştur.

Araştırmada kullanılan anketin geliştirilmesinde; Mahmut BOZAN'ın "Merkeziyetçi Yönetimden Yerinden Yönetime Geçişte Alternatif Yaklaşımlar" konulu doktora tezinden, Yasemin (KOÇAK) USLUEL'in "Milli Eğitim Bakanlığı Merkez Örgütü Yöneticilerinin Yerelleşme Konusundaki Görüşleri” konulu doktora tezinden, Fatma BARKÇİN'in "Eğitim Yönetiminde Yetki Devri" konulu doktora tezinden, Esergül Balcı BUCAK'ın "Eğitimde Yerelleşme" konulu kitabından yararlanılmıştır.

Anket iki bölümden oluşmaktadır. Anketin birinci bölümde deneklerin kişisel bilgileriyle ilgili üç soru, ikinci bölümünde ise yirmi önerme yer almaktadır. Soru ve önermelerle verilen cevapların tüm denekler için frekans (f) ve yüzde (\%), dağılımları alınmıştır. Anketin ikinci bölümünde yer alan Milli Eğitim Bakanlığı taşra örgütü yöneticileri ve denetçilerinin görüşleri arasında görev unvanı, eğitim durumu ve yöneticilik kıdemi değişkenleri açısından farklılık gösterip göstermediğini belirlemek için, aritmetik ortalama $(\bar{X})$, standart sapma (SS), tek yönlü varyans analizi (F) ve Scheffe testi uygulanmıştır. Veriler SPSS 10.0 (The Statistical Packet for The Social Sciences) paket programı kullanılarak çözümlenmiştir.

Ankette; Milli Eğitim Bakanlığı merkez örgütünün mevcut durumuyla işlevlerini etkili bir biçimde yerine getirip getirmediği konusunda 1 madde, Milli Eğitim Bakanlığı merkez örgütünün yetkilerini yerel örgütlere devretmesi ve Türk eğitim sisteminin yeniden yapılandırılması konusunda 1 madde, Milli Eğitim Bakanlığı merkez örgütünün yetkilerini yerel düzeydeki örgütlere devretmesi durumunda uygulamadaki yararları ve sakıncaları konusunda 13 madde, eğitim yönetiminin iş gören, eğitim programları ve öğretim, bütçe, genel hizmetler alanlarında merkez örgütünde bulunan yetkilerin yerelleştirilmesi konusunda 5 madde yer almaktadır. 


\section{BULGULAR ve YORUM}

Araştırmaya katılan denekler görev unvanlarına göre incelendiğinde, ilköğretim müfettişleri genel dağılımın \%76.6'sını oluşturmaktadır. Eğitim yöneticileri ise genel dağılımın \%23.4'ünü oluşturmaktadır. Eğitim yöneticileri arasında en büyük kümeyi şefler oluşturmaktadır (\%12.8).

Araștırmaya katılan denekler eğitim durumlarına göre incelendiğinde lisans mezunları genel dağılımın \%82.2'sini oluşturmaktadır. Yüksek lisans ve üzerinde eğitim alanların oranı ise oldukça düşüktür (\%6).

Araştırmaya katılan denekler yöneticilik kıdemi durumlarına göre incelendiğinde 21 yıl ve daha çok çalışanlar genel dağılımın \%43.6'sının oluşturmaktadır.

Araştırmanının birinci sorusu "Milli Eğitim Bakanlığı taşra örgütünde görev yapan eğitim yöneticileri ve denetçilerinin Milli Eğitim Bakanlığının merkeziyetçi yapısı ve merkez örgütünün taşra örgütlerine yetki devretmesi konusundaki görüşleri nedir?" olarak ifade edilmiştir. Bu soruya ilişkin eğitim yöneticileri ve denetçilerinin görüşlerinin aritmetik ortalamaları ve standart sapmaları aşağıdaki çizelgede verilmiştir.

Milli Eğitim Bakanlığının Merkeziyetçi Yapısı ve Merkez Örgütünün Taşra Örgütlerine Yetki Devretmesine İlişkin Görüşler

\begin{tabular}{clrrr}
\hline Önerme NO & \multicolumn{1}{c}{ Önermeler } & N & $\bar{X}$ & SS \\
\hline \multirow{2}{*}{1} & $\begin{array}{l}\text { Milli Eğitim Bakanlığ karar verme yetkisinin } \\
\text { üst yönetim birimlerinde toplandığı merkezi- } \\
\text { yetçi yapısılyla işlevlerini etkili bir biçimde } \\
\text { yerine getirmektedir. }\end{array}$ & 2.58 & 1.15 \\
& $\begin{array}{l}\text { Milli Eğitim Bakanlığı merkez örgütü yetkile- } \\
\text { rini yerel örgütlere devretmeli ve Türk eğitim } \\
\text { sistemi yeniden yapılandırılmalıdır. }\end{array}$ & 3.73 & 1.20 \\
\hline
\end{tabular}

Bu bulgulara bakılarak eğitim yöneticileri ve denetçileri Milli Eğitim Bakanlığının karar verme yetkisinin üst yönetim birimlerinde toplandığ merkeziyetçi yapısıyla işlevlerini etkili bir biçimde yerine getiremediği ( $\bar{X}=2.58$ ), Bu nedenle Milli Eğitim Bakanlığı merkez örgütünün yetkilerini yerel örgütlere devretmesi ve Türk eğitim sisteminin yeniden yapılandırılmasının gerekli olduğu ( $\bar{X}=3.73$ ) görüşündedirler.

Araştırmanının ikinci sorusu; "Milli Eğitim Bakanlığı taşra örgütü yöneticileri ve denetçilerinin taşra örgütlerine yetki devredilmesinin yararları ve sakıncaları konusundaki görüşleri nedir?" olarak ifade edilmiștir. Bu alt probleme ilişkin eğitim yöneticileri ve denetçilerinin görüşlerinin aritmetik ortalamaları ve standart sapmaları aşağıdaki çizelgede verilmiştir. 
Milli Eğitim Bakanlığı Taşra Örgütlerine Yetki Devredilmesinin Yararları ve Sakıncalarına İliş̧kin Görüsşler

\begin{tabular}{|c|c|c|c|c|}
\hline $\begin{array}{l}\text { Önerme } \\
\text { NO }\end{array}$ & Önermeler & $\mathbf{N}$ & $\bar{X}$ & SS \\
\hline 3 & $\begin{array}{l}\text { Yerelleşme ile yerel örgütlere yetki aktarılmasıyla merkez } \\
\text { örgütünün iş yükü, bürokratik gecikmeler ve kırtasiyecilik } \\
\text { azalır. Yerel düzeydeki görevlere atanan memurlar yerel } \\
\text { sorunlara karşı daha duyarlı olur. }\end{array}$ & 436 & 3.71 & 1.09 \\
\hline 4 & $\begin{array}{l}\text { Milli Eğitim Bakanlığı merkez örgütü yerel örgütlerden gelen } \\
\text { bilgileri kullanarak daha gerçekçi ve etkili eğitim politikaları } \\
\text { oluşturur. }\end{array}$ & 436 & 3.82 & 1.05 \\
\hline 5 & $\begin{array}{l}\text { Yerelleşme ile yetki devredilerek yönetim kapasitesi artırılan } \\
\text { yerel örgütler merkez örgütünün gerçekleştiremediği görevleri } \\
\text { yerine getirir. }\end{array}$ & 436 & 3.51 & 1.02 \\
\hline 6 & $\begin{array}{l}\text { Yerel düzeyde eğitimle ilgili kararlar daha çabuk alınır, yerel } \\
\text { halkın eğitimle ilgili karar alma sürecine katılması sağlanarak } \\
\text { demokratikleşme gerçekleştirilir. }\end{array}$ & 436 & 3.62 & 1.10 \\
\hline 7 & $\begin{array}{l}\text { Yerelleşme ile eğitim etkinlikleri eğitim ihtiyaçlarına ve yerel } \\
\text { koşullara uygun olarak halkın katkıları ile daha az maliyetle } \\
\text { yürütülür. }\end{array}$ & 436 & 3.63 & 1.05 \\
\hline 8 & $\begin{array}{l}\text { Yerelleşme ile yerel düzeyde bulunan eğitim araç-gereçleri, } \\
\text { personel, bina ve diğer kaynaklar daha verimli kullanılır. }\end{array}$ & 436 & 3.80 & 1.03 \\
\hline 9 & $\begin{array}{l}\text { Yerelleşme ile ekonomik ve sosyal kalkınma daha hızlı } \\
\text { gerçekleşir. }\end{array}$ & 436 & 3.50 & 1.05 \\
\hline 10 & $\begin{array}{l}\text { Yerelleşme ile merkez örgütünün yerel eğitim kurumlarını } \\
\text { denetlemesi azalır. }\end{array}$ & 436 & 3.22 & 1.18 \\
\hline 11 & Yerelleşme ile merkez örgütünün güç ve otoritesi azalır. & 436 & 2.95 & 1.20 \\
\hline 12 & $\begin{array}{l}\text { Yerelleşme ile halk arasındaki nüfuzlu kişiler kendi çıkarları } \\
\text { yönünde eğitim yönetimini etkiler, eğitimde tarafsızlığ } \\
\text { sağlamak zorlaşır. }\end{array}$ & 436 & 3.56 & 1.22 \\
\hline 13 & Yerelleşme ile eğitimin milli birliği sağlama işlevi azalır. & 436 & 3.19 & 1.26 \\
\hline 14 & $\begin{array}{l}\text { Yerelleşme ile yerel düzeyde yürütülen eğitim etkinliklerinin } \\
\text { ulusal düzeydeki eğitim standartlarına uygun olarak yürütül- } \\
\text { mesi zorlaşır. }\end{array}$ & 436 & 3.13 & 1.21 \\
\hline 15 & $\begin{array}{l}\text { Yerelleşme ile yerel örgütlerde eğitim yöneticilerinin halk } \\
\text { tarafından daha çok ilgi gören hizmetlere yönelmesi eğitimin } \\
\text { genel amaçlarından ve ilkelerinden uzaklaşılmasına neden } \\
\text { olur. }\end{array}$ & 436 & 3.45 & 1.16 \\
\hline
\end{tabular}

$\mathrm{Bu}$ bulgulara bakılarak eğitim yöneticileri ve denetçileri Milli Eğitim Bakanlığı merkez örgütünün elinde bulunan yetkilerin yerelleşmesinin yarar11 olacağı görüşündedirler ( $\bar{X}=3.66$ ). Eğitim yöneticileri ve denetçileri Milli Eğitim Bakanlığı merkez örgütünün elinde bulunan yetkilerin yerelleşmesinin sakıncalarına ilişkin görüşlerinde bir kararsızlık görünmektedir $(\bar{X}=3.25)$. 
Araştırmanının üçüncü sorusu; “ Milli Eğitim Bakanlığı taşra örgütü yöneticileri ve denetçilerinin; iş gören, eğitim programları ve öğretim, bütçe, genel hizmetler konularında yerel örgütlerin yetkili olması konusundaki görüşleri nedir?" olarak ifade edilmiştir. Bu alt probleme ilişkin eğitim yöneticileri ve denetçilerinin görüşlerinin aritmetik ortalamaları ve standart sapmaları aşağıdaki çizelgede verilmiş̧ir.

\section{Yerel Örgütler Tarafından Yürütülmesi Öngörülen Eğitim Yönetimi} Etkinliklerine İlişkin Görüşler

\begin{tabular}{|c|c|c|c|c|}
\hline $\begin{array}{l}\text { Önerme } \\
\text { NO }\end{array}$ & Önermeler & $\mathbf{N}$ & $\bar{X}$ & SS \\
\hline 16 & $\begin{array}{l}\text { Eğitim kurumlarında görevlendirilecek yönetici, } \\
\text { öğretmen, sözleşmeli ve kadrolu diğer eğitim iş } \\
\text { görenlerinin istihdam edilmesi yerel düzeyde planla- } \\
\text { nıp yürütülmelidir. }\end{array}$ & 436 & 3.43 & 1.22 \\
\hline 17 & $\begin{array}{l}\text { Eğitim iş görenlerinin yer değişikliği, ödül, ceza ve } \\
\text { diğer özlük işlemleri yerel düzeyde yürütülmelidir. }\end{array}$ & 436 & 3.22 & 1.21 \\
\hline 18 & $\begin{array}{l}\text { Eğitim programlarının geliştirilmesi, eğitim program- } \\
\text { larındaki ortak ve seçmeli derslerin içeriklerinin, ders } \\
\text { saatlerinin ve kredilerinin belirlenmesi işlemleri yerel } \\
\text { düzeyde yürütülmelidir. }\end{array}$ & 436 & 3.06 & 1.29 \\
\hline 19 & $\begin{array}{l}\text { Okul yapımı için arsa, bina yapımı, binaların onarımı } \\
\text { işleri yerel düzeyde planlanıp gerekli olan kaynak } \\
\text { yerel kaynaklardan sağlanmalıdır. }\end{array}$ & 436 & 3.78 & 1.08 \\
\hline 20 & $\begin{array}{l}\text { Eğitim araç-gereçlerinin temin edilmesi bakım ve } \\
\text { onarımı ile kurumları elektrik, su, haberleşme, } \\
\text { 1sınma vb. giderleri yerel kaynaklardan karşılanmal1- } \\
\text { dır. }\end{array}$ & 436 & 3.66 & 1.13 \\
\hline
\end{tabular}

Bu bulgulara bakılarak eğitim yöneticileri ve denetçileri yukarıdaki çizelgede ifade edilen eğitim yönetimi etkinliklerinin yerel örgütler tarafindan yürütülmesi görüşündedirler ( $\bar{X}=3.43$ ).

Araştırmanının dördüncü sorusu; "Milli Eğitim Bakanlığı taşra örgütü yöneticileri ve denetçilerinin görüşleri arasında; görev unvanlarına göre anlamlı farklılık var mıdır?, eğitim durumlarına göre anlamlı farklılık var mıdır?, yöneticilik kıdemlerine göre anlamlı farklılık var mıdır?" olarak ifade edilmiştir. Eğitim yöneticileri ve denetçilerinin görüşleri arasında görev unvanlarına göre anlamlı fark olup olmadığına ilişkin çizelge aşağıda verilmiştir.

"Yerelleşme ile yerel düzeyde bulunan eğitim araç-gereçleri, iş gören, bina ve diğer kaynaklar daha verimli kullanılır." önermesindeki görüşleri değerlendirilirken $\mathrm{F}=7.038$ olarak bulunmuş, scheffe testi sonucuna göre ilköğretim müfettişleri ile şefler arasında $\alpha=0.05$ düzeyinde anlamlı farklı- 
lık olduğu görülmüştür. Müdür yardımcıları ile şefler arasında $\alpha=0.05$ düzeyinde anlamlı farklılık olduğu görülmüştür. Müdür yardımcıları bu görüşe, şeflere göre $\bar{X}=4.09$ ile "katılıyorum" derecesinde daha fazla katılmaktadır. İlköğretim müfettişleri ise bu görüşe, şeflere göre $\bar{X}=3.89$ ile "katılıyorum" derecesinde daha fazla katılmaktadır.

"Yerelleşme ile ekonomik ve sosyal kalkınma daha hızlı gerçekleşir." önermesindeki görüşleri değerlendirilirken $F=7.945$ olarak bulunmuş, scheffe testi sonucuna göre ilköğretim müfettişleri ile müdür yardımcıları arasında $\alpha=0.05$ düzeyinde anlamlı farklılık olduğu görülmüştür. İlköğretim müfettişleri ile şefler arasında $\alpha=0.05$ düzeyinde anlamlı farklılık olduğu görülmüsstür. Müdür yardımcıları ile şefler arasında $\alpha=0.05$ düzeyinde anlamlı farkl1lık olduğu görülmüsstür. Müdür yardımcıları bu görüşe, ilköğretim müfettişlerine ve şeflere göre $\bar{X}=4.27$ ile "tamamen katıliyorum" derecesinde daha fazla katılmaktadır. İlköğretim müfettişleri bu görüşe, şeflere göre $\bar{X}=3.51$ ile "katılıyorum" derecesinde daha fazla katılmaktadır.

"Yerelleşme ile halk arasındaki nüfuzlu kişiler kendi çıkarları yönünde eğitim yönetimini etkiler, eğitimde tarafsızlığı sağlamak zorlaşır." önermesindeki görüşleri değerlendirilirken $F=3.233$ olarak bulunmuş, scheffe testi sonucuna göre müdür yardımcıları ile şefler arasında $\alpha=0.05$ düzeyinde anlamlı farklılık olduğu görülmüştür. Şefler bu görüşe, müdür yardımcılarına göre $\bar{X}=3.86$ ile "katılıyorum" derecesinde daha fazla katılarak yerelleşme ile halk arasındaki nüfuzlu kişilerin kendi çıkarları yönünde eğitim yönetimini etkileyeceği, eğitimde tarafsızlığı sağlamanın zorlaşacağını düşünmektedir. Müdür yardımcıları ise bu görüşe $\bar{X}=2.91$ ile "kararsızım" derecesinde katılarak Yerelleşme ile halk arasındaki nüfuzlu kişilerin kendi çıkarları yönünde eğitim yönetimini etkileyebileceği, eğitimde tarafsılı̆ı̆ı sağlamanın zorlaşacağı konusunda daha dikkatli olunması gerektiğini düşünmektedir.

"Yerelleşme ile eğitimin milli birliği sağlama işlevi azalır." önermesindeki görüşleri değerlendirilirken $F=7.760$ olarak bulunmuş, scheffe testi sonucuna göre ilköğretim müfettişleri ile müdür yardımcıları arasında $\alpha=0.05$ düzeyinde anlamlı farkl1lık olduğu görülmüştür. Müdür yardımcıları ile şefler arasında $\alpha=0.05$ düzeyinde anlamlı farklılık olduğu görülmüştür. İlköğretim müfettişleri bu görüşe, müdür yardımcılarına ve şeflere göre $\bar{X}=3.29$ ile "kararsızım" derecesinde daha fazla katılmaktadır. Şefler bu görüşe, müdür yardımcılarına göre $\bar{X}=3.14$ ile "kararsızım" derecesinde daha fazla katılmaktadır. Müdür yardımcıları ise $\bar{X}=2.00$ ile "katılmıyo- 
rum" derecesinde görüş belirterek yerelleşme ile eğitimin milli birliği sağlama işlevinin azalacağını düşünmemektedir.

"Yerelleşme ile yerel düzeyde yürütülen eğitim etkinliklerinin ulusal düzeydeki eğitim standartlarına uygun olarak yürütülmesi zorlaşır." önermesindeki görüşleri değerlendirilirken $\mathrm{F}=3.444$ olarak bulunmuş, scheffe testi sonucuna göre ilköğretim müfettişleri ile müdür yardımcıları arasında $\alpha=0.05$ düzeyinde anlamlı farkl1lık olduğu görülmüştür. Müdür yardımcıları ile şefler arasında $\alpha=0.05$ düzeyinde anlamlı farklılık olduğu görülmüştür. İlköğretim müfettişleri bu görüşe, müdür yardımcılarına ve şeflere göre $\bar{X}=3.14$ ile "kararsızım" derecesinde daha fazla katılmaktadır. Şefler bu görüsşe, müdür yardımcılarına göre $\bar{X}=3.25$ ile "kararsızım" derecesinde daha fazla katılmaktadır. Müdür yardımcıları ise $\bar{X}=2.36$ ile "katılmıyorum" derecesinde görüş belirterek yerelleşme ile yerel düzeyde yürütülen eğitim etkinliklerinin ulusal düzeydeki eğitim standartlarına uygun olarak yürütülmesinin zorlaşacağını düşünmemektedir.

"Yerelleşme ile yerel örgütlerde eğitim yöneticilerinin halk tarafindan daha çok ilgi gören hizmetlere yönelmesi eğitimin genel amaçlarından ve ilkelerinden uzaklaşılmasına neden olur." önermesindeki görüşleri değerlendirilirken $\mathrm{F}=4.795$ olarak bulunmuş, scheffe testi sonucuna göre ilköğretim müfettişleri ile müdür yardımcıları arasında $\alpha=0.05$ düzeyinde anlamlı farklılık olduğu görülmüștür. Müdür yardımcıları ile şube müdürleri arasında $\alpha=0.05$ düzeyinde anlamlı farklılık olduğu görülmüsstür. Müdür yardımcılar1 ile şefler arasında $\alpha=0.05$ düzeyinde anlamlı farklılık olduğu görülmüştür. İlköğretim müfettişleri bu görüşe, müdür yardımcılarına göre $\bar{X}=3.46$ ile "katılıyorum" derecesinde daha fazla katılmaktadır. Şube müdürleri bu görüşe, müdür yardımcılarına göre $\bar{X}=3.83$ ile "katılıyorum" derecesinde daha fazla katılmaktadır. Şefler bu görüsse, müdür yardımcılarına göre $\bar{X}=3.57$ ile "katıllyorum" derecesinde daha fazla katılmaktadır. Müdür yardımcıları dışındaki eğitim yöneticileri ve denetçileri yerelleşme ile yerel örgütlerde eğitim yöneticilerinin halk tarafından daha çok ilgi gören hizmetlere yönelmesinin eğitimin genel amaçlarından ve ilkelerinden uzaklaşılmasına neden olacağı görüşüne katılırken müdür yardımcıları $\bar{X}=2.64$ ile "kararsızım" derecesinde görüss belirterek bu konuda daha dikkatli olunması gerektiğini düşünmektedir.

"Eğitim kurumlarında görevlendirilecek yönetici, öğretmen, sözleşmeli ve kadrolu diğer eğitim iş görenlerinin istihdam edilmesi yerel düzeyde planlanıp yürütülmelidir." önermesindeki görüşleri değerlendirilirken $F=4.873$ olarak bulunmuş, scheffe testi sonucuna göre ilköğretim müfettişleri ile şube 
müdürleri arasında $\alpha=0.05$ düzeyinde anlamlı farklılık olduğu görülmüştür. Şube müdürleri ile şefler arasında $\alpha=0.05$ düzeyinde anlamlı farklılık olduğu görülmüştür. Şube müdürleri bu görüşe, ilköğretim müfettişlerine ve şeflere göre $\bar{X}=4.17$ ile "katılıyorum" derecesinde daha fazla katılmaktadır. İlköğretim müfettişleri $\bar{X}=3.37$ ile "kararsızım" derecesinde ve şefler $\bar{X}=3.25$ ile "kararsızım" derecesinde görüş belirterek bu konuda daha dikkatli olunması gerektiğini düşünmektedir.

"Eğitim iş görenlerinin yer değişikliği, ödül, ceza ve diğer özlük işlemleri yerel düzeyde yürütülmelidir." önermesindeki görüşleri değerlendirilirken $\mathrm{F}=5.311$ olarak bulunmuş, scheffe testi sonucuna göre ilköğretim müfettişleri ile müdür yardımcıları arasında $\alpha=0.05$ düzeyinde anlamlı farklılık olduğu görülmüştür. Müdür yardımcıları bu görüşe, ilköğretim müfettişlerine göre $\bar{X}=3.92$ ile "kat1liyorum" derecesinde daha fazla katılmaktadır. İlköğretim müfettişleri ise $\bar{X}=3.11$ ile "kararsızım" derecesinde görüş belirterek bu konuda daha dikkatli olunması gerektiğini düşünmektedir.

"Eğitim programlarının geliştirilmesi, eğitim programlarındaki ortak ve seçmeli derslerin içeriklerinin, ders saatlerinin ve kredilerinin belirlenmesi işlemleri yerel düzeyde yürütülmelidir." önermesindeki görüşleri değerlendirilirken $\mathrm{F}=2.858$ olarak bulunmuş, scheffe testi sonucuna göre ilköğretim müfettişleri ile müdür yardımcıları arasında $\alpha=0.05$ düzeyinde anlamlı farklılık olduğu görülmüştür. Müdür yardımcıları bu görüşe, ilköğretim müfettişlerine göre $\bar{X}=3.82$ ile "katılıyorum" derecesinde daha fazla katılmaktadır. Müdür yardımcıları dışındaki eğitim yöneticileri ve deneticileri "kararsızım" derecesinde görüş belirterek bu konuda daha dikkatli olunması gerektiğini düşünmektedir.

"Eğitim araç-gereçlerinin temin edilmesi bakım ve onarımı ile kurumların elektrik, su, haberleşme, 1sınma vb. giderleri yerel kaynaklardan karş1lanmalıdır." önermesindeki görüşleri değerlendirilirken $\mathrm{F}=10.289$ olarak bulunmuş, scheffe testi sonucuna göre ilköğretim müfettişleri ile şefler arasında $\alpha=0.05$ düzeyinde anlamlı farkl1lık olduğu görülmüştür. İlköğretim müfettişleri bu görüşe, şeflere göre $\bar{X}=3.80$ ile "katıllyorum" derecesinde daha fazla katılmaktadır. Şefler ise $\bar{X}=2.93$ ile "kararsızım" derecesinde görüş belirterek bu konuda daha dikkatli olunması gerektiğini düşünmektedir.

"Milli Eğitim Bakanlığı karar verme yetkisinin üst yönetim birimlerinde toplandığı merkeziyetçi yapısıyla işlevlerini etkili bir biçimde yerine getirmektedir." önermesindeki görüşleri değerlendirilirken $F=4.297$ olarak bu- 
lunmuş, scheffe testi sonucuna göre ön lisans mezunları ile yüksek lisans ve üzeri eğitim alanlar arasında $\alpha=0.05$ düzeyinde anlamlı farklılık olduğu görülmüştür. Ön lisans mezunları bu görüşe, yüksek lisans ve üzeri eğitim alanlara göre $\bar{X}=2.88$ ile "kararsızım" derecesinde daha fazla katılarak Milli Eğitim Bakanlığının karar verme yetkisinin üst yönetim birimlerinde toplandığı merkeziyetçi yapısıyla işlevlerini etkili bir biçimde yerine getirdiği konusunda kararsızlık içindedir. Yüksek lisans ve üzeri eğitim alanlar ise bu görüşe $\bar{X}=2.08$ ile "katılmıyorum" derecesinde katılarak Milli Eğitim Bakanlığının karar verme yetkisinin üst yönetim birimlerinde toplandığı merkeziyetçi yapısıyla işlevlerini etkili bir biçimde yerine getirdiğini düşünmemektedir

"Okul yapımı için arsa, bina yapımı, binaların onarımı işleri yerel düzeyde planlanıp gerekli olan kaynak yerel kaynaklardan sağlanmalıdır." önermesindeki görüşleri değerlendirilirken $\mathrm{F}=4.389$ olarak bulunmuş, scheffe testi sonucuna göre ön lisans mezunları ile lisans mezunları arasında $\alpha=0.05$ düzeyinde anlamlı farklılık olduğu görülmüştür. Lisans mezunları bu görüşe, ön lisans mezunlarına göre $\bar{X}=4.84$ ile "katılıyorum" derecesinde daha fazla katılmaktadır. Ön lisans mezunları ise bu görüşe $\bar{X}=3.36$ ile "kararsızım" derecesinde görüş belirterek bu konuda daha dikkatli olunması gerektiğini düşünmektedir.

"Eğitim araç-gereçlerinin temin edilmesi bakım ve onarımı ile kurumların elektrik, su, haberleşme, 1sınma vb. giderleri yerel kaynaklardan karş1lanmalıdır." önermesindeki görüşleri değerlendirilirken $\mathrm{F}=4.367$ olarak bulunmuş, scheffe testi sonucuna göre ön lisans mezunları ile lisans mezunlar1 arasında $\alpha=0.05$ düzeyinde anlamlı farklılık olduğu görülmüştür. Ön lisans mezunları ile yüksek lisans ve üzeri eğitim alanlar arasında $\alpha=0.05$ düzeyinde anlamlı farkl1l1k olduğu görülmüştür. Lisans mezunları bu görüşe, ön lisans mezunlarına göre $\bar{X}=3.69$ ile "katıliyorum" derecesinde daha fazla katılmaktadır. Yüksek lisans ve üzeri eğitim alanlar bu görüşe, ön lisans mezunlarına göre $\bar{X}=3.92$ ile "kat1liyorum" derecesinde daha fazla katılmaktadır. Ön lisans mezunları ise $\bar{X}=3.11$ ile "kararsızım" derecesinde görüş belirterek bu konuda daha dikkatli olunması gerektiğini düşünmektedir.

"Yerelleşme ile yerel düzeyde bulunan eğitim araç-gereçleri, personel, bina ve diğer kaynaklar daha verimli kullanılır." önermesindeki görüşleri değerlendirilirken $\mathrm{F}=3.784$ olarak bulunmuş, scheffe testi sonucuna göre yöneticilik kıdemi 1-5 yıl olan eğitim yöneticileri ve denetçileri ile yöneticilik kıdemi 21 yıl ve daha fazla olan eğitim yöneticileri ve denetçileri arasın- 
da $\alpha=0.05$ düzeyinde anlamlı farkl11ık olduğu görülmüştür. Yöneticilik kıdemi 21 yıl ve daha fazla olan eğitim yöneticileri ve denetçileri bu görüşe yöneticilik k1demi 1-5 yıl olan eğitim yöneticileri ve denetçilerine göre $\bar{X}=3.92$ ile "kat1liyorum" derecesinde daha fazla katılmaktadır.

"Yerelleşme ile ekonomik ve sosyal kalkınma daha hızlı gerçekleşir." önermesindeki görüşleri değerlendiriliken $\mathrm{F}=4.786$ olarak bulunmuş, scheffe testi sonucuna göre yöneticilik kıdemi 6-10 yıl olan eğitim yöneticileri ve denetçileri ile yöneticilik kıdemi 21 yıl ve daha fazla olan eğitim yöneticileri ve denetçileri arasında $\alpha=0.05$ düzeyinde anlamlı farklılık olduğu görülmüsşür. Yöneticilik kıdemi 21 yıl ve daha fazla olan eğitim yöneticileri ve denetçileri bu görüşe yöneticilik kıdemi 6-10 yıl olan eğitim yöneticileri ve denetçilerine göre $\bar{X}=3.65$ ile "katıliyorum" derecesinde daha fazla katılmaktadır. Yöneticilik kıdemi 10 yıldan fazla olan eğitim yöneticileri ve denetçileri yerelleşme ile ekonomik ve sosyal kalkınmanın daha hızlı gerçekleşeceğini düşünmektedirler. Yöneticilik kıdemleri 10 yıldan az olan eğitim yöneticileri ve denetçileri ise yerelleşme ile ekonomik ve sosyal kalkınmanın daha hızlı gerçekleşeceği konusunda kararsızlık içindedir.

"Yerelleşme ile merkez örgütünün yerel eğitim kurumlarını denetlemesi azalır." önermesindeki görüşleri değerlendirilirken $\mathrm{F}=2.796$ olarak bulunmuş, scheffe testi sonucuna göre yöneticilik kıdemi 16-20 yıl olan eğitim yöneticileri ve denetçileri ile yöneticilik kıdemi 21 yıl ve daha fazla olan eğitim yöneticileri ve denetçileri arasında $\bar{X}=0.05$ düzeyinde anlamlı farkl1lık olduğu görülmüştür. Yöneticilik kıdemi 21 yıl ve daha fazla olan eğitim yöneticileri ve denetçileri bu görüşe yöneticilik kıdemi 16-20 yıl olan eğitim yöneticileri ve denetçilerine göre $\bar{X}=3.31$ ile "kararsızım" derecesinde daha fazla katılmaktadır.

"Yerelleşme ile eğitimin milli birliği sağlama işlevi azalır." önermesindeki görüşleri değerlendirilirken $F=4.011$ olarak bulunmuş, scheffe testi sonucuna göre yöneticilik kıdemi 6-10 yıl olan eğitim yöneticileri ve denetçileri ile yöneticilik kıdemi 16-20 yıl olan eğitim yöneticileri ve denetçileri arasında $\alpha=0.05$ düzeyinde anlamlı farklılık olduğu görülmüştür. Yöneticilik kıdemi 11-15 yıl olan eğitim yöneticileri ve denetçileri ile yöneticilik kıdemi 16-20 yıl olan eğitim yöneticileri ve denetçileri arasında $\alpha=0.05$ düzeyinde anlamlı farklılık olduğu görülmüştür. Yöneticilik kıdemi 16-20 yıl olan eğitim yöneticileri ve denetçileri ile yöneticilik kıdemi 21 yıl ve daha fazla olan eğitim yöneticileri ve denetçileri arasında $\alpha=0.05$ düzeyinde anlamlı farklılık olduğu görülmüştür. Yöneticilik kıdemi 6-10 y1l olan eğitim yöneticileri ve denetçileri bu görüşe yöneticilik kıdemi 16-20 y1l olan eğitim 
yöneticileri ve denetçilerine göre $\bar{X}=3.42$ ile "katılıyorum" derecesinde daha fazla katılmaktadır. Yöneticilik kıdemi 11-15 yıl olan eğitim yöneticileri ve denetçileri bu görüsse yöneticilik kıdemi $16-20$ yıl olan eğitim yöneticileri ve denetçilerine göre $\bar{X}=3.40$ ile "katıllyorum" derecesinde daha fazla katılmaktadır. Yöneticilik kıdemi 21 yıl ve daha fazla olan eğitim yöneticileri ve denetçileri bu görüşe yöneticilik kıdemi 16-20 yıl olan eğitim yöneticileri ve denetçilerine göre $\bar{X}=3.21$ ile "kararsızım" derecesinde daha fazla katılmaktadır.

"Eğitim iş görenlerinin yer değişikliği, ödül, ceza ve diğer özlük işlemleri yerel düzeyde yürütülmelidir.” önermesindeki görüşleri değerlendirilirken $F=4.034$ olarak bulunmuş, scheffe testi sonucuna göre yöneticilik kıdemi 6-10 yıl olan eğitim yöneticileri ve denetçileri ile yöneticilik kıdemi 1115 yıl olan eğitim yöneticileri ve denetçileri arasında $\alpha=0.05$ düzeyinde anlamlı farklılık olduğu görülmüştür. Yöneticilik k1demi 11-15 y1l olan eğitim yöneticileri ve denetçileri bu görüşe, yöneticilik kıdemi 6-10 yıl olan eğitim yöneticileri ve deneticilerine göre $\bar{X}=3.53$ ile "kat1lyorum" derecesinde daha fazla katılmaktadır. Yöneticilik kıdemi 11-15 yıl olan eğitim yöneticileri ve denetçileri eğitim iş görenlerinin yer değişikliği, ödül, ceza ve diğer özlük işlemlerinin yerel düzeyde yürütülmesi gerektiğini düşünmektedir. Buna karşılık yöneticilik kıdemi 6-10 yıl olan eğitim yöneticileri ve denetçileri başta olmak üzere yöneticilik kıdemi 11-15 y1l olan eğitim yöneticileri ve denetçileri dışında kalan eğitim yöneticileri ve denetçilerinin tamamı "kararsızım" derecesinde görüş belirterek eğitim iş görenlerinin yer değişikliği, ödül, ceza ve diğer özlük işlemlerinin yerel düzeyde yürütülmesi konusunda kararsızlık içindedir.

"Eğitim araç-gereçlerinin temin edilmesi bakım ve onarımı ile kurumların elektrik, su, haberleşme, 1sınma vb. giderleri yerel kaynaklardan karş1lanmalıdır." önermesindeki görüşleri değerlendirilirken $\mathrm{F}=5.172$ olarak bulunmuş, scheffe testi sonucuna göre yöneticilik kıdemi 1-5 yıl olan eğitim yöneticileri ve denetçileri ile yöneticilik kıdemi 6-10 yıl olan eğitim yöneticileri ve denetçileri arasında $\alpha=0.05$ düzeyinde anlamlı farklılık olduğu görülmüştür. Yöneticilik kıdemi 6-10 yıl olan eğitim yöneticileri ve denetçileri ile yöneticilik kıdemi $16-20$ yıl olan eğitim yöneticileri ve denetçileri arasında $\alpha=0.05$ düzeyinde anlamlı farklılık olduğu görülmüştür. Yöneticilik kıdemi 6-10 y1l olan eğitim yöneticileri ve denetçileri bu görüşe, yöneticilik kıdemi 1-5 y1l olan eğitim yöneticileri ve denetçilerine göre ve yöneticilik kıdemi 16-20 y1l olan eğitim yöneticileri ve denetçilerine göre $\bar{X}=4.03$ ile "katılıyorum" derecesinde daha fazla katılmaktadır. 


\section{SONUC}

Araştırma bulgularına dayanılarak şu sonuçlara ulaşılmıştır;

Eğitim yöneticileri ve denetçilerinin \%64'ten fazlası Milli Eğitim Bakanlığının karar verme yetkisinin üst yönetim birimlerinde toplandığı merkeziyetçi yapısıyla işlevlerini etkili bir şekilde yerine getiremediği görüşündedirler. Dolayısıyla eğitim sisteminde yaşanan sorunların Milli Eğitim Bakanlığı merkez örgütünde bulunan yetkilerin işin yapıldığg yerel örgütlere devredilmesi ile çözümlenebileceği yönünde görüş bildirmişlerdir.

Eğitim yöneticileri ve deneticilerinin \%70'ten fazlas1 ankette yer alan Milli Eğitim Bakanlığı merkez örgütünün elinde bulunan yetkilerin yerelleştirilmesinin yararlı olacağ 1 görüşündedir. Buna karşılık eğitim yöneticileri ve denetçilerinin \%60'tan fazlası Milli Eğitim Bakanlığ 1 merkez örgütünün elinde bulunan yetkilerin yerelleştirilmesi durumunda halk arasındaki nüfuzlu kişilerin kendi çıarları yönünde eğitim yönetimini etkileyeceği, böylece eğitimde tarafsızlığı sağlamanın güçleşeceği Eğitim yöneticileri ve denetçilerinin \%60'tan fazlası Milli Eğitim Bakanlığı merkez örgütünün elinde bulunan yetkilerin yerelleştirilmesi durumunda yerel örgütlerde görevli eğitim yöneticilerinin halk tarafından daha çok ilgi gören hizmetlere yönelmesiyle eğitimin genel amaç ve ilkelerinden uzaklaşılacağı görüşündedirler.

Eğitim yöneticileri ve denetçilerinin \%73'ten fazlası ankette yer alan yerel örgütler tarafından yürütülmesi öngörülen eğitim yönetimi etkinliklerine ilişkin beş önermeden üçünde yerel örgütlere yetki devredilmesinin uygun olacağı görüşündedirler. Bu önermeler şunlardır:

Önerme 19. Okul yapımı için arsa, bina yapımı, binaların onarımı işleri yerel düzeyde planlanıp gerekli olan kaynak yerel kaynaklardan sağlanmalı$\operatorname{dir}(\bar{X}=3.78)$.

Önerme 20: Eğitim araç-gereçlerinin temin edilmesi bakım ve onarımı ile kurumların elektrik, su, haberleşme, 1sınma vb. giderleri yerel kaynaklardan karşılanmalıdır ( $\bar{X}=3.66)$.

Önerme 16: Eğitim kurumlarında görevlendirilecek yönetici, öğretmen, sözleşmeli ve kadrolu diğer eğitim iş görenlerinin istihdam edilmesi yerel düzeyde planlanıp yürütülmelidir ( $\bar{X}=3.43$ ).

\section{ÖNERILER}

Milli Eğitim Bakanlığında merkez örgütünün sahip olduğu bazı yetkilerin yerel örgütlere devredilmesi konusunda bakanlık taşra örgütünde görev yapan eğitim yöneticileri ve denetçilerinin dikkate alınması eğitimde yerel- 
leşme çabalarının başarıya ulaşmasını sağlayacaktır. Milli eğitim Bakanlığının örgütsel yapısı, taşra ve merkez olarak şûra vb. çalışmalarda değerlendirilebilir. Bu çalışmaların sonucuna yönelik olarak sistemin merkeziyetçi yapıdan kurtarılması yoluna gidilebilir. $\mathrm{Bu}$ amaçla hukuki düzenleme yapılabilir, merkez ve taşra örgütleri arasında koordinasyon etkili biçimde sağlanabilir.

Yerel örgütlere yetki devredilmesi halinde ortaya çıkacak sakıncalı durumların belirlenmesinde eğitim yöneticileri ve denetçilerinin görüşlerine yer verilmesi, sakıncalı durumların daha net ortaya konulmasını sağlayacaktır. Yetkinin merkezden taşraya göçerilmesi çalışmalarında bu konunun paydaşlarının (Milli Eğitim Bakanlığı merkez ve taşra yöneticileri ve denetçileri ile il idaresi) görüşleri alınabilir.

Eğitim yöneticileri ve denetçilerinin en çok tedirgin olduğu halk arasındaki nüfuzlu kişilerin kendi çıkarları yönünde eğitim yönetimini etkilemesi ve eğitim yöneticilerinin halk tarafindan daha çok ilgi gören hizmetlere yönelmesi hususlarına yapılacak hukuki düzenlemelerde yer verilebilir ve önleyici tedbirler alınabilir.

Yerel örgütlere yetki devredilmesi konusunda yetki devrinden etkilenecek olan öğretmen ve okul yöneticilerinin de görüşlerinin alınması gerekmektedir.

Eğitim hizmetlerinin yerel örgütlere devredilmesiyle birlikte ortaya çıkacak kaynak ve uzman personel ihtiyacının giderilmesi için il idaresini düzenleyen hukuki metinlerin yeniden düzenlenmesi sağlanabilir. 


\section{KAYNAKÇA}

Aydın, A. (1999). Milli Ĕgitim Bakanlı̆̆ı Merkez Örgütünde Yetki Devri Sorunu. 4. Ulusal Eğitim Bilimleri Kongresi Bildirileri, Eskişehir.

Aydın, M. (2000). Eğitim Yönetimi. Ankara: Hatipoğlu Yayınları.

Balcı Bucak, E.(2000). Eğitimde Yerelleşme. Ankara: Detay Yayıncılık.

Barkçin, F. (1994). "Eğitim Yönetiminde Yetki Devri." Yayınlanmamış doktora tezi, Gazi Üniversitesi Sosyal Bilimler Enstitüsü, Ankara.

Başar, E. (2004). Milli Eğitim Bakanlarının Eğitim Faaliyetleri. İstanbul: Milli Eğitim Bakanlığı Yayınları.

Bozan, M. (2002). "Merkeziyetçi Yönetimden Yerinden Yönetime Geçişte Alternatif Yaklaşımlar.”Yayınlanmamış doktora tezi, İnönü Üniversitesi Sosyal Bilimler Enstitüsü, Malatya.

Bursalığlu, Z. (1994). Okul Yönetiminde Yeni Yapı ve Davranış (9.Baskı). Ankara: Pegem Yayıncilık.

DPT, Dokuzuncu Kalkınma Planı (2007-2013), Ankara 2006.

Duman, A. (1998). Eğitimin Yerinden Yönetimi. Çağdaş Yerel Yönetimler Dergisi, 7(2).

Elma, C. ve Demir, K. (Ed.) (2003) Yönetimde Çağdaş Yaklaşımlar. Ankara: An1 Yayınc1lik.

Erdoğan, İ. (1996). Eğitim Sisteminin Yerelleşmesi. Yeni Türkiye Dergisi, 96(7).

Keleş, Ruşen. (2000). Yerinden Yönetim ve Siyaset. İstanbul: Cem Yayınevi.

Koçak (Usluel), Y. (1995). "Milli Eğitim Bakanlığı Merkez Örgütü Yöneticilerinin Yerelleşme Konusundaki Görüşleri”. Yayınlanmamış doktora tezi, Hacettepe Üniversitesi Sosyal Bilimler Enstitüsü, Ankara.

Özden, Y. (1999). Eğitimde Dönüşüm Eğitimde Yeni Değerler (2.Bask1). Ankara: Pegem Yayıncilık.

Şişman, M. ve Turan, S. (2003). Eğitimde Yerelleşme ve Demokratikleşme Çabaları. Kuram ve Uygulamada Eğitim Yönetimi Dergisi, 34. Ankara: Pegem Yayıncılık.

\section{Internet Referansları}

http://www.dpt.gov.tr

http://www.meb.gov.tr http://ilsis.meb.gov.tr 